\title{
Benefits of Cardamom (Elettaria cardamomum (L.) Maton) and Turmeric (Curcuma longa L.) Extracts for Their Applications as Natural Anti-Inflammatory Adjuvants
}

\author{
Gustavo R. Cárdenas Garza ${ }^{1}$, Joel H. Elizondo Luévano ${ }^{2}{ }^{\circledR}$, Aldo F. Bazaldúa Rodríguez ${ }^{2}{ }^{\circledR}$, \\ Abelardo Chávez Montes ${ }^{2}{ }^{1}$, Raymundo A. Pérez Hernández ${ }^{1}{ }^{\mathbb{D}}$, Ameyalli J. Martínez Delgado ${ }^{1}$, \\ Sonia M. López Villarreal ${ }^{1} \mathbb{D}$, José Rodríguez Rodríguez ${ }^{3} \mathbb{1}$, Rosa M. Sánchez Casas ${ }^{4}$, \\ Uziel Castillo Velázquez ${ }^{4, *(1)}$ and Osvelia E. Rodríguez Luis $1, *($ )
}

1 Faculty of Dentistry, Autonomous University of Nuevo León, Monterrey 64460, NL, Mexico; gustavo.cardenasgrz@uanl.edu.mx (G.R.C.G.); raymundo.perezhrz@uanl.edu.mx (R.A.P.H.); ameyalli.martinezd@uanl.edu.mx (A.J.M.D.); sonia.lopezvl@uanl.edu.mx (S.M.L.V.)

2 Faculty of Biological Sciences, Autonomous University of Nuevo León, San Nicolás de los Garza 66455, NL, Mexico; joel.elizondolv@uanl.edu.mx (J.H.E.L.); aldo.bazalduarg@uanl.edu.mx (A.F.B.R.);

check for updates

Citation: Cárdenas Garza, G.R.; Elizondo Luévano, J.H.; Bazaldúa Rodríguez, A.F.; Chávez Montes, A.; Pérez Hernández, R.A.; Martínez Delgado, A.J.; López Villarreal, S.M.; Rodríguez Rodríguez, J.; Sánchez Casas, R.M.; Castillo Velázquez, U.; et al. Benefits of Cardamom (Elettaria cardamomum (L.) Maton) and Turmeric (Curcuma longa L.) Extracts for Their Applications as Natural Anti-Inflammatory Adjuvants. Plants 2021, 10, 1908. https://doi.org/ 10.3390/plants10091908

Academic Editors: Seok-Geun Lee and In Jin $\mathrm{Ha}$

Received: 20 July 2021

Accepted: 8 September 2021

Published: 14 September 2021

Publisher's Note: MDPI stays neutral with regard to jurisdictional claims in published maps and institutional affiliations.

Copyright: (c) 2021 by the authors. Licensee MDPI, Basel, Switzerland. This article is an open access article distributed under the terms and conditions of the Creative Commons Attribution (CC BY) license (https:// creativecommons.org/licenses/by/ $4.0 /)$. abelardo.chavezmn@uanl.edu.mx (A.C.M.)

3 Tecnológico de Monterrey, Monterrey 64849, NL, Mexico; jrr@tec.mx

4 Faculty of Veterinary Medicine and Zootechny, Autonomous University of Nuevo León, Monterrey 64460, NL, Mexico; rosa.sanchezcss@uanl.edu.mx

* Correspondence: uziel.castillovl@uanl.edu.mx (U.C.V.); osvelia.rodriguezls@uanl.edu.mx (O.E.R.L.); Tel.: +52-8113404390 (U.C.V.); +52-8183294230 (ext. 3117) (O.E.R.L.)

Abstract: The genus Zingiberaceae has been widely used for phytotherapeutic purposes in traditional medicine throughout the world for its anti-inflammatory activity. Experimental studies have established that inflammation caused by chronic infections represents a risk factor for different forms of cancer. The objective of this study was focused on determining the anti-inflammatory capacity and cytotoxic activity of aqueous extracts of Elettaria cardamomum (cardamom) and Curcuma Longa (turmeric). The extracts were obtained by maceration and, through GC-MS/MS, a total of 11 different chemical components were determined in the aqueous extract of cardamom and 7 in the extract of turmeric. The main compounds found in cardamom and turmeric were $\alpha$-terpinyl acetate $(54.46 \%)$ and $\beta$-turmerone (33.45\%), respectively. RT-qPCR results showed significantly lower gene expression levels of innate inflammatory cytokines (IL-6 and TNF- $\alpha$ ) compared to the control (LPS). Also, it was observed that the extracts do not possess cytotoxic activity against different cell lines, where E. cardamomum showed $\mathrm{EC}_{50}(\mu \mathrm{g} / \mathrm{mL}$ ) of 473.84 (HeLa cells), 237.36 (J774A.1 cells), 257.51 (Vero E6 cells), and 431.16 (Balb/C peritoneal cells) and C. longa showed EC $50(\mu \mathrm{g} / \mathrm{mL})$ of 351.17 (HeLa cells), 430.96 (J774A.1 cells), 396.24 (Vero E6 cells), and 362.86 (Balb/C peritoneal cells). The results of this research suggest that natural extracts of E. cardamomum and C. longa possess anti-inflammatory effects and no cytotoxic activity against HeLa, J774A.1, Vero E6, and Balb/C peritoneal cell lines. Finally, it was observed that the extracts also decreased nitric oxide (NO) production in peritoneal macrophages.

Keywords: anti-inflammatory; Curcuma longa; cytokines; cytotoxic activity; Elettaria cardamomum; extracts; inflammation; medicinal plants; natural products; phytochemicals

\section{Introduction}

Nowadays, there is a tendency to incorporate phytotherapy as an efficient therapeutic option worldwide; the use of medicinal plants to treat various pathologies has been reported since they possess active principles with different biological actions [1,2]. The World Health Organization (WHO) encourages the use of plants with a scientific basis for the therapy of systemic diseases [3]. These diseases can lead to serious complications, 
activating the inflammation process with infiltration of macrophages, neutrophils, lymphocytes, and plasma cells in the tissue, with the release of cytokines that contribute to the repair of tissue damage [4]. The inflammation process occurs as a response to aggression to repair and restore tissues [5]. During this period, cytokines, proteins that regulate the function of immune system cells produced by lymphocytes, macrophages, or monocytes and hematopoietic cells with pro-inflammatory or anti-inflammatory action, are released [6]. Among the proinflammatory cytokines are tumor necrosis factor-alpha (TNF- $\alpha$ ), interleukin-1 $\alpha$ (IL-1 $\alpha$ ), interleukin-1 $\beta$ (IL-1 $\beta)$, interleukin-6 (IL-6), interleukin-17 (IL-17), and, with antagonistic effects, interleukin-10 (IL-10) [7,8]. Current therapy involves anti-inflammatory agents that, in some cases, may reveal adverse effects such as the presence of a peptic ulcer, gastrointestinal toxicity, myocardial infarction, heart failure, stroke, or nephrotoxicity $[9,10]$.

In traditional medicine, the antioxidant and pharmaceutical properties of some plants belonging to the Zingiberaceae family, such as Elettaria cardamomum and Curcuma longa, have been well studied, and have found applications in industries such as food, cosmetics, and pharmaceuticals, among others; these capabilities are related to their diverse composition of various phytochemical compounds, mainly phenolic compounds [11]. E. cardamomum (cardamom), also known as "green or true cardamom", is a perennial herbaceous plant, which has been described as possessing compounds such as phenols, starch, tannins, terpenoids, flavonoids, proteins, sterols [12], anthocyanins, and alkaloids, and it also possesses various pharmacological properties, such as antioxidant, anti-inflammatory, anticancer, and antimicrobial activities [13]. C. longa, also called turmeric or curcuma, possesses different bioactive components such as curcuminoids (curcumin) and essential oils (monoterpenes) [14], and among its multiple therapeutic properties are anti-inflammatory, antihyperlipidemic, antimicrobial, and antiparasitic activity $[15,16]$. Its traditional use has been reported for the treatment of diseases such as rheumatoid arthritis, multiple sclerosis, and psoriasis as it manages to modulate the signaling of proinflammatory cytokines [17].

The main objective of this research focused on the evaluation of the effects of crude aqueous extracts of E. cardamomum and C. longa on the inflammatory process through the expression of interleukins by stimulated macrophages and their possible applications as adjuvants in health improvement therapies.

\section{Materials and Methods}

\subsection{Chemicals and Reagents}

All chemicals and solvents were analytical grade. Antibiotic antimycotic solution $(100 \times)$ stabilized, diethyl polycarbonate (DEPC), dimethyl sulfoxide (DMSO), Dulbecco's Modified Eagle Medium (DMEM), fetal bovine serum (FBS), glycine buffer solution, Griess reagent, guanidine thiocyanate, lipopolysaccharide (LPS) from Escherichia coli O26:B6 smooth strain, n-hexane, nystatin, RNAzol ${ }^{\circledR}$ RT, RPMI-1640 medium with L-glutamine, SYBR $^{\circledR}$ Green Quantitative RT-qPCR kit, and thiazolyl blue tetrazolium bromide (MTT) were purchased from Sigma-Aldrich (Merck KGaA, Darmstadt, Germany). GoTaq ${ }^{\circledR}$ qPCR Master Mix kit and ImProm-II ${ }^{\mathrm{TM}}$ Reverse Transcription System reverse transcription kit was purchased from Promega (Promega ${ }^{\circledR}$ Corporation, Madison, WI, USA).

\subsection{Plant Material and Extraction}

E. cardamomum seeds (SKU: 209740-01) and C. longa rhizome (SKU: 205400-54) were both purchased from Starwest Botanicals (Sacramento, CA, USA). Plant material was purchased in powdered form. The extraction was performed with distilled water. Aqueous extracts of both plants were obtained by the heat infusion method $\left(100{ }^{\circ} \mathrm{C} / 100 \mathrm{rpm}\right)$ for $30 \mathrm{~min}$. For this purpose, $10 \mathrm{~g}$ of plant material were placed in $100 \mathrm{~mL}$ of distilled water in a flat-bottomed ball flask. After the extraction time, the extracts were filtered, frozen 
at $-80{ }^{\circ} \mathrm{C}$, and, finally, lyophilized. The following formula was used to calculate the extraction yield percentage [18]:

$$
\% \text { Yield }=\left(\frac{\text { Final weight }}{\text { Initial weight }}\right) \times 100
$$

\subsection{Qualitative Phytochemical Tests}

The following phytochemical tests were performed to identify the functional groups of each extract: Lieberman-Buchard (sterols, triterpenes), Shinoda (flavonoids), Baljet (sesquiterpene lactones), sulfuric acid (quinones), and ferric chloride (tannins) [19], then each extract was analyzed by gas chromatography coupled to GC/MS mass for identification of the main components of its chemical composition [11].

\subsection{GC and GC-MS/MS Analysis of the Aqueous Extracts}

For chemical identification and quantification, $1 \mu \mathrm{L}$ of diluted aqueous extract in n-hexane $(1: 20, v: v)$ was analyzed using a gas chromatograph Varian Saturn 2100T coupled to an MS/MS Saturn 2100 ion trap mass spectrometer (Agilent Technologies, Inc., Walnut Creek, CA, USA). The chromatographic separation was performed with the capillary column HP-5ms $(30 \mathrm{~m} \times 0.25 \mathrm{~mm} \times 0.25 \mu \mathrm{m})$. The split injection mode was used (split ratio 1:20), while helium-6 was used as the carrier gas with a flow rate of $1 \mathrm{~mL} \mathrm{~min}^{-1}$. The injector temperature was set to $250^{\circ} \mathrm{C}$. The initial oven temperature was set to $70^{\circ} \mathrm{C}$ for $1 \mathrm{~min}$, then the temperature was raised to $150{ }^{\circ} \mathrm{C}$ at a rate of $5^{\circ} \mathrm{C}$ per min and held at this temperature for $5 \mathrm{~min}$. In addition, the column was heated up to $200{ }^{\circ} \mathrm{C}$ at a rate of $10^{\circ} \mathrm{C}$ and, finally, kept at $200^{\circ} \mathrm{C}$ for $15 \mathrm{~min}$. The total running time was $60 \mathrm{~min}$. The mass spectra were recorded in the SCAN mode in a range from 30 to $400 \mathrm{~m} / \mathrm{z}$ using electron ionization energy at $70 \mathrm{eV}$ and the detector temperature was set to $150{ }^{\circ} \mathrm{C}$ [11]. The GC-MS structure analysis was performed using the National Institute Standard and Technology (NIST) database; in addition, the results were compared with results from previous studies available in the literature $[20,21]$.

2.5. Gene Expression of Anti-Inflammatory Cytokines on Peritoneal Macrophages Stimulated with Aqueous Extracts and Challenged with Lipopolysaccharide

To evaluate the anti-inflammatory effects of aqueous extracts of E. cardamomum and C. longa, murine macrophages were challenged with lipopolysaccharide (LPS; Escherichia coli serotype O26:B6 smooth strain) to induce a classical activation phenotype [22]. Relative quantification of proinflammatory cytokine gene sequences IL-4, IL-6, IL-10, and TNF- $\alpha$ induced by aqueous extracts of E. cardamomum and C. longa, as well as LPS, were measured by real-time quantitative PCR (RT-qPCR) using SYBR ${ }^{\circledR}$ Green reagent.

\subsubsection{Obtaining Peritoneal Cells}

Five female Balb/C mice were inoculated intraperitoneally (IP) with $1 \mathrm{~mL}$ of DMEM, then sacrificed by cervical dislocation, and a gentle massage of the abdomen was performed. The culture medium with the cells in the peritoneal fluid was extracted and centrifuged at $2700 \mathrm{rpm}\left(4^{\circ} \mathrm{C}\right)$ for ten minutes, eliminating the supernatant and conserving the cell pellet, which was homogenized with the aqueous extract individually (Table 1). Finally, it was incubated for $30 \mathrm{~min}$ at $37^{\circ} \mathrm{C}\left(\mathrm{CO}_{2} 5 \%\right)$, centrifuged, and the supernatant was eliminated [23]. Two washes were performed with phosphate buffer (PBS, ph 7.4) and then homogenized with $500 \mu \mathrm{L}$ of RNAzol ${ }^{\circledR}$. As an inducer of inflammation in macrophages, $50 \mu \mathrm{g} / \mathrm{mL}$ of LPS was used as a positive control [24]. The concentrations of the extracts were obtained from microbicide assays in which these concentrations were used (data not shown). 
Table 1. Concentrations of aqueous extracts evaluated.

\begin{tabular}{cc}
\hline Aqueous Extract & Concentration $(\mu \mathrm{g} / \mathrm{mL})$ \\
\hline E. cardamomum & 100 \\
C. longa & 70 \\
\hline
\end{tabular}

\subsubsection{RNA Extraction}

Extraction of total ribonucleic acid (RNA) from peritoneal macrophages was performed from samples suspended in the cell lysis reagent $\mathrm{RNAzol}^{\circledR}$, guanidine thiocyanate. Subsequently, total RNA extraction was performed according to the manufacturer's instructions. Once the total RNA pellet was obtained, it was suspended in $20 \mu \mathrm{L}$ of nuclease-free water obtained by DEPC treatment. The total RNA pellet obtained was quantified in a NanoDrop ${ }^{\mathrm{TM}}$ ND-1000 spectrophotometer (Thermo Fisher Scientific Inc., Wilmington, DE, USA) at optical densities (OD) of 260 and $280 \mathrm{~nm}$; for this purpose, total RNA was suspended in $20 \mu \mathrm{L}$ of nuclease-free water. The extraction purity and concentration showed a variation of 1.98 and 2.09 and a concentration ranging from 485.45 to $940.39 \mathrm{ng} / \mu \mathrm{L}$ for each of the triplicates [24].

\subsubsection{Complementary DNA (cDNA) Synthesis}

From the previously obtained total RNA, complementary DNA (cDNA) synthesis was performed using the ImProm-II ${ }^{\mathrm{TM}}$ Reverse Transcription System reverse transcription kit. For each reaction, $4 \mu \mathrm{L}$ of ImProm-II ${ }^{\mathrm{TM}} 5 \mathrm{X}$ reaction buffer, $1 \mu \mathrm{L}$ of the dNTP's mixture (0.5 mM of each), $2.4 \mu \mathrm{L}$ of $\mathrm{MgCl}_{2}(25 \mathrm{mM}), 1 \mu \mathrm{L}$ of Oligo(dT) ${ }_{15}$ primer, $1 \mu \mathrm{L}$ of ImProm-II ${ }^{\mathrm{TM}}$ transcriptase, $1500 \mathrm{ng}$ of RNA quencher, and nuclease-free water were mixed to a final volume of $20 \mu \mathrm{L}$. The reactions were carried out in $200 \mu \mathrm{L}$ capacity microtubes. The prepared samples were incubated in a thermal cycler $\left(\right.$ Veriti $^{\circledR}$, Applied Biosystems ${ }^{\circledR}$, Waltham, MA, USA) to carry out cDNA synthesis, the reaction conditions used were as follows: $25^{\circ} \mathrm{C}$ (5 min), $42{ }^{\circ} \mathrm{C}(60 \mathrm{~min}), 70^{\circ} \mathrm{C}(15 \mathrm{~min})$, and $4{ }^{\circ} \mathrm{C}(\infty)$. Once the retrotranscription was completed, the concentration and purity of the cDNA obtained were determined using an $\mathrm{EPOCH}^{\mathrm{TM}}$ microplate spectrophotometer (BioTek Instruments, Inc., Winooski, VT, USA) with the Gen 5 software for microplate reading and data analysis. Finally, the products obtained were stored at $-80^{\circ} \mathrm{C}$ until further use.

\subsubsection{Oligonucleotide Design}

The design of oligonucleotides for the quantification of cytokines (IL-4, IL-6, IL-10, and TNF- $\alpha$ ) and endogenous genes ( $\beta$-actin and Gpd-1) was performed from the mRNA sequence of each gene, obtained from Genbank. (Table 2). The oligonucleotides for the amplification of the eight selected sequences were designed using the Primer Quest ${ }^{\mathrm{TM}}$ Tool online program from IDT ${ }^{\mathrm{TM}}$ (Integrated DNA Technologies, Inc., Coralville, IA, USA), which was responsible for performing the synthesis of the oligonucleotides used in this project. The oligonucleotides were designed according to the following specifications: approximate size of $20 \mathrm{bp}$, melting temperature of $60^{\circ} \mathrm{C}$, and a guanine-cytokine content of $55 \%$. The oligonucleotides obtained were analyzed using the PRIMER BLAST program to verify their specificity with the sequence of interest. 
Table 2. Sequences of oligonucleotides used for RT-qPCR.

\begin{tabular}{|c|c|c|}
\hline Gene & Genebank ID & Oligonucleotides \\
\hline IL-4 & NM_021283.2 & $\begin{array}{l}\text { F: } 5^{\prime} \text { TTG AGA GAG ATC ATC GGC ATT T }-3^{\prime} \\
\text { R: } 5^{\prime} \text { CTC ACT CTC TGT GGT GTT CTT C - } 3^{\prime}\end{array}$ \\
\hline IL-6 & NM_031168.2 & $\begin{array}{c}\text { F: } 5^{\prime} \text { CTT CCA TCC AGT TGC CTT CT }-3^{\prime} \\
\text { R: } 5^{\prime} \text { CTC CGA CTT GTG AAG TGG TAT AG }-3^{\prime}\end{array}$ \\
\hline IL-10 & NM_010548.2 & $\begin{array}{c}\text { F: } 5^{\prime} \text { TTG AAT TCC CTG GGT GAG AAG -3' } \\
\text { R: } 5^{\prime} \text { TCC ACT GCC TTG CTC TTA TTT }-3^{\prime}\end{array}$ \\
\hline Gpd1 & NM_010271.3 & $\begin{array}{l}\text { F: } 5^{\prime} \text { CCT ACT GCT GAC CTT TCT TCT C }-3^{\prime} \\
\text { R: } 5^{\prime} \text { GCC CTG AGG ACG ATA AAC TAT AA }-3^{\prime}\end{array}$ \\
\hline TNF- $\alpha$ & NM_013693.3 & $\begin{array}{c}\text { F: } 5^{\prime} \text { TTG TCT ACT CCC AGG TTC TCT }-3^{\prime} \\
\text { R: } 5^{\prime} \text { GAG GTT GAC TTT CTC CTG GTA TG }-3^{\prime}\end{array}$ \\
\hline$\beta$-actin & NM_07393.5 & $\begin{array}{c}\text { F: } 5^{\prime}-\text { GAG GTA TCC TGA CCC TGA AGT A - } 3^{\prime} \\
\text { R: } 5^{\prime}-\text { CAC ACG CAG CTC ATT GTA GA - } 3^{\prime}\end{array}$ \\
\hline
\end{tabular}

F: Forward; R: Reverse.

\subsubsection{Real Time-qPCR (RT-qPCR)}

Quantification of gene expression by RT-qPCR was calculated using the $2^{-\Delta \Delta C t}$ method, which consisted of subtracting the threshold cycle (Ct) of the endogenous gene (Gpd1) from the $\mathrm{Ct}$ of the gene of interest, thus obtaining the $\Delta \mathrm{Ct}$, then the average $\Delta \mathrm{Ct}$ of the control group was obtained and this was subtracted from the $\Delta \mathrm{Ct}$ of each of the biological samples, thus calculating the $\Delta \Delta \mathrm{Ct}$, and, finally, the formula $2^{-\Delta \Delta \mathrm{Ct}}$ was applied. The $\mathrm{Ct}$ was determined based on the default baseline assigned by the system [25]. The amplification reaction was performed using the GoTaq ${ }^{\circledR}$ qPCR Master Mix kit at a final volume of $20 \mu \mathrm{L}$ for each sample, including $10 \mu \mathrm{L}$ of the GoTaq qPCR Mix (2x), $1 \mu \mathrm{L}$ of the oligonucleotide pair of interest that $(100 \mu \mathrm{M}), 1 \mu \mathrm{L}$ of the cDNA of interest (75 ng), and, finally, the reaction was completed with $8 \mu \mathrm{L}$ of nuclease-free water. The qPCR reactions were carried out in a 96-well PCR microplate (Axygen Scientific ${ }^{\circledR}$, Union City, CA, USA) coated with Platemax ${ }^{\circledR}$ UltraClear Sealing Film (Axygen Scientific ${ }^{\circledR}$, Union City, CA, USA). Each sample was placed in triplicate in the plate and, in addition, a control reaction was included, which consisted of adding all the reagents used to perform the amplification reaction except cDNA.

\subsection{Index of Cytotoxicity of the Aqueous Extract of E. cardamomum and C. longa on Cell Cultures}

For the evaluation of cytotoxicity of the aqueous extracts of E. cardamomum and C. longa, three cell lines were used, cervical cancer (HeLa, ATCC CCL-2), mouse macrophages (J774A.1, ATCC TIB-67), and African green monkey kidney (Vero E6, ATCC CRL-1586). All cells were maintained in RPMI-1640 medium, which contained L-glutamine, 10\% FBS, and antibiotic/antifungal (penicillin, streptomycin, and amphotericin B), and were kept in incubation at $37^{\circ} \mathrm{C}\left(5 \% \mathrm{CO}_{2}\right)$ in Corning ${ }^{\circledR} 25 \mathrm{~cm}^{2}$ cell culture flasks (Merck KGaA, Darmstadt, Germany). Medium changes were carried out every third day. Passages were made when the cells reached approximately $80 \%$ confluence. Next, $100 \mu \mathrm{L}$ of culture medium containing $5 \times 10^{4}$ cells/well of each cell line were placed in a 96-well microplate and the different serial concentrations of the aqueous extract of E. cardamomum and C. longa were added, ranging from 3.125 to $200 \mu \mathrm{g} / \mathrm{mL}$ ( $200 \mu \mathrm{L}$ final volume), which were then incubated for $24 \mathrm{~h}$. A positive control (nystatin 100,000 $\mu \mathrm{L} / \mathrm{mL}$ ) and negative control (cells without treatment) were also included. Once the treatment time with the extracts was fulfilled, the MTT colorimetric test was carried out [23]. The culture medium was extracted and, subsequently, the plates were washed with PBS and $100 \mu \mathrm{L}$ of tetrazolium salt MTT was added in $0.25 \mathrm{mg} / \mathrm{mL}$ to the non-supplemented medium. The plates were incubated at $37^{\circ} \mathrm{C} / 4 \mathrm{~h}$. After that time, the supernatant was removed and $100 \mu \mathrm{L}$ of DMSO $+20 \mu \mathrm{L}$ of glycine buffer was added and incubated for $30 \mathrm{~min}$ to allow the formazan crystals to dissolve [26]. Subsequently, the absorbance was read on an $\mathrm{EPOCH}^{\mathrm{TM}}$ microplate reader at $570 \mathrm{~nm}$ and was analyzed with Gen5 software. Similarly, the same tests were performed on mouse $(\mathrm{Balb} / \mathrm{C})$ peritoneal macrophages to observe changes or differences that could 
be found between commercial and ex vivo cells. Percentage of cytotoxicity was calculated according to Equation (2) and the $\mathrm{IC}_{50}$ was determined [18].

$$
\% \text { Cytotoxicity }=\left(\frac{\text { Abs of the sample }}{\text { Abs control }}\right) \times 100
$$

\subsection{Nitric Oxide Assay}

To perform the nitric oxide (NO) assay, peritoneal cells were cultured for $22 \mathrm{~h}$ with $100 \mu \mathrm{g} / \mathrm{mL}$ of aqueous extract of E. cardamomum and $70 \mu \mathrm{g} / \mathrm{mL}$ of aqueous extract of C. longa. As an inflammation model, $50 \mathrm{ng} / \mathrm{mL}$ of LPS from E. coli O26:B6 smooth strain was used to induce a classical activation phenotype associated with an inflammatory process by NO production, determined by nitrite accumulation in the supernatant using Griess reagent [27].

\subsection{Statistical Analysis}

All results were expressed as mean value \pm standard deviation. Each experiment was performed in triplicate independently in at least three replicates. The IBM-SPSS software (Ver. 22, IBM Corp., Armonk, NY, USA) was used for the statistical evaluation of the results obtained. For that purpose, a one-way analysis of variance (ANOVA) at a 95\% confidence level and a Tukey post hoc test was applied. GraphPad Prism 6 was used to generate the graphs. The half-maximal effective concentration $\left(\mathrm{EC}_{50}\right)$ was determined by the Probit test.

\section{Results}

\subsection{Phytochemical Tests}

The aqueous extract of E. cardamomum was positive for sterols, triterpenes, flavonoids, sesquiterpene lactones, and tannins. The extract of $C$. longa was positive for sterols, triterpenes, flavonoids, and sesquiterpene lactones (Table 3). Both extracts were negative for quinones. The extraction yields were $5.64 \%$ and $9.83 \%$, respectively.

Table 3. Phytochemical tests.

\begin{tabular}{cccc}
\hline Test & Chemical Groups & E. cardamomum & C. longa \\
\hline Lieberman Burchard & Sterols, triterpenes & + & + \\
Shinoda & Flavonoids & + & + \\
Baljet & Sesquiterpene lactones & + & + \\
Sulfuric acid & Quinones & - & - \\
Ferric chloride & Tannins & + & - \\
\hline Yield \% & & 5.64 & 9.83 \\
\hline + Positive reaction; - negative reaction.
\end{tabular}

\subsection{Compound Identification}

To identify the compounds of interest, GC-MS/MS-based phytochemical analysis of the aqueous extracts was performed (Table 4); the analyses resulted in the identification of 11 major compounds in E. cardamomum, the $\alpha$-terpinyl acetate, 2-((1R,4R)4-hydroxy-4-methylcyclohex-2-enyl) propan-2-yl acetate, 9-hexacosene, heneicosane, 8acetoxycarvotanacetone, geranyl oleate, $\gamma$-sitosterol, naphthalene, decahydro-4a-methyl-1methylene-7-(1-methylethenyl)-,[4aR-(4a $\alpha, 7 \alpha, 8 \mathrm{a} \alpha)], \alpha$-terpineol, (Z)-3,7-dimethylocta-2,6dien-1-yl palmitate, and pentacosane (Figure 1a). In C. longa, $\beta$-turmerone, $\alpha$-turmerone, Ar-turmerone, 16-kauren-19-yl acetate, $\alpha$-atlantone, $\beta$-sesquiphellandrene, and benzene were identified (Figure 1b). The compounds identified in both aqueous extracts represent the bioactive compounds previously reported for both plants [11]. 
Table 4. Main chemical composition of aqueous extracts of two Zingiberaceae plants identified by GC-MS/MS.

\begin{tabular}{|c|c|c|c|c|}
\hline Plant Extract & Chemical Compound & R.T. & P.A. \% & M.W. (g/mol) \\
\hline \multirow{11}{*}{$\begin{array}{l}\text { E. cadamomum } \\
\text { (Cardamom) }\end{array}$} & $\alpha$-terpinyl acetate & 10.27 & 54.46 & 196.29 \\
\hline & $\begin{array}{l}\text { 2-((1R,4R)-4-hydroxy-4-methylcyclohex-2-enyl) } \\
\text { propan-2-yl acetate }\end{array}$ & 11.31 & 3.55 & 212.28 \\
\hline & 9-hexacosene & 26.96 & 3.52 & 364.69 \\
\hline & $\gamma$-sitoesterol & 29.93 & 3.38 & 414.71 \\
\hline & Heneicosane & 24.73 & 3.04 & 296.57 \\
\hline & 8-acetoxycarvotanacetone & 12.93 & 2.57 & 210.27 \\
\hline & Geranyl oleate & 27.24 & 2.28 & 418.70 \\
\hline & (Z)-3,7-dimethylocta-2,6-dien-1-yl palmitate & 26.31 & 2.08 & 392.70 \\
\hline & $\begin{array}{c}\text { Naphthalene, decahydro-4a-methyl-1-methylene-7-(1- } \\
\text { methylethenyl)-, } \\
{[4 \mathrm{aR}-(4 \mathrm{a} \alpha, 7 \alpha, 8 \mathrm{a} \alpha)]-}\end{array}$ & 12.05 & 2.03 & 204.35 \\
\hline & $\alpha$-terpineol & 8.12 & 1.95 & 154.25 \\
\hline & Pentacosane & 25.99 & 1.85 & 352.68 \\
\hline \multirow{7}{*}{$\begin{array}{l}\text { C. longa } \\
\text { (Turmeric) }\end{array}$} & $\beta$-turmerone & 15.51 & 33.45 & 218.33 \\
\hline & $\alpha$-turmerone & 15.95 & 21.30 & 218.33 \\
\hline & Ar-turmerone & 15.57 & 19.85 & 216.32 \\
\hline & 16-kauren-19-yl acetate & 27.08 & 18.72 & 330.26 \\
\hline & $\alpha$-atlantone & 16.80 & 2.77 & 218.33 \\
\hline & $\beta$-sesquiphellandrene & 13.84 & 1.98 & 204.35 \\
\hline & Benzene & 13.31 & 1.93 & 78.11 \\
\hline
\end{tabular}

R.T.: retention time; P.A. \%: peak area percent; M.W.: molecular weight.

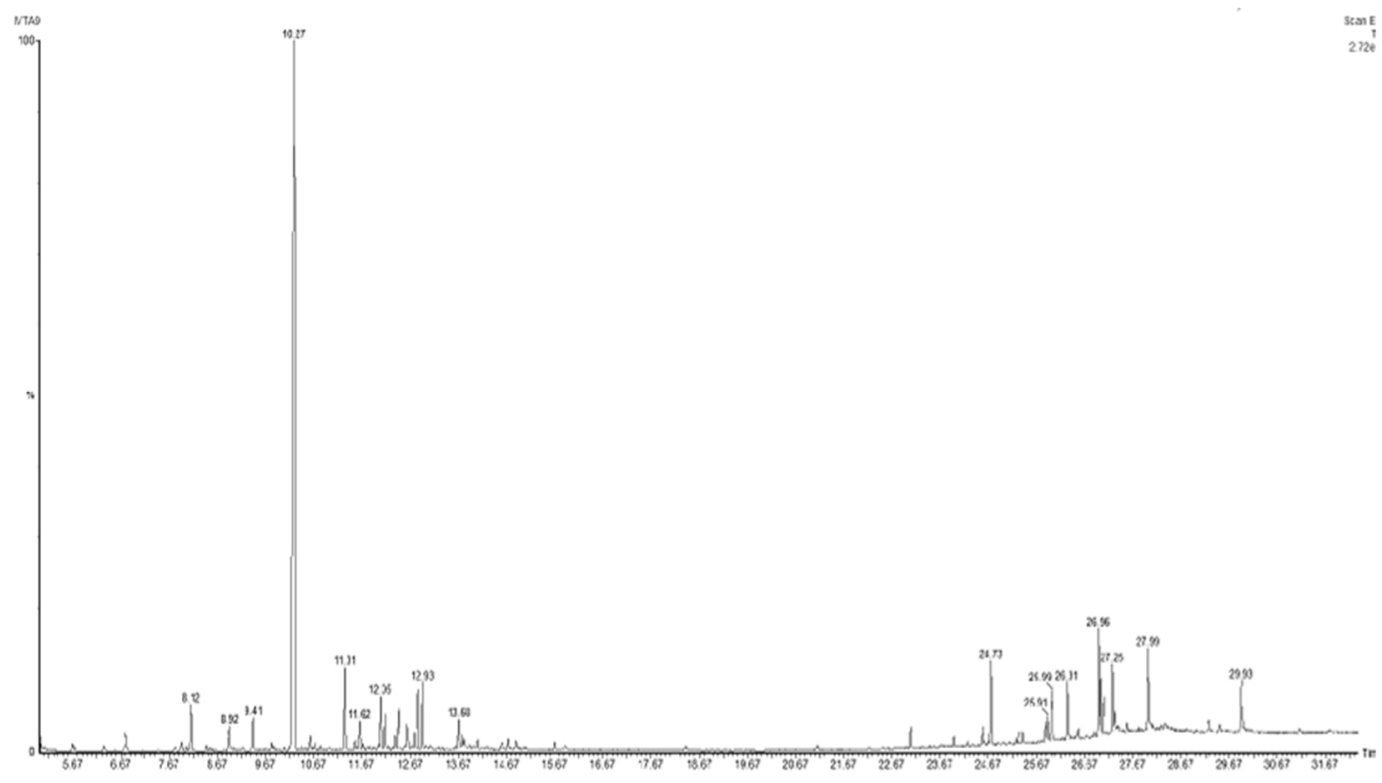

(a)

Figure 1. Cont. 


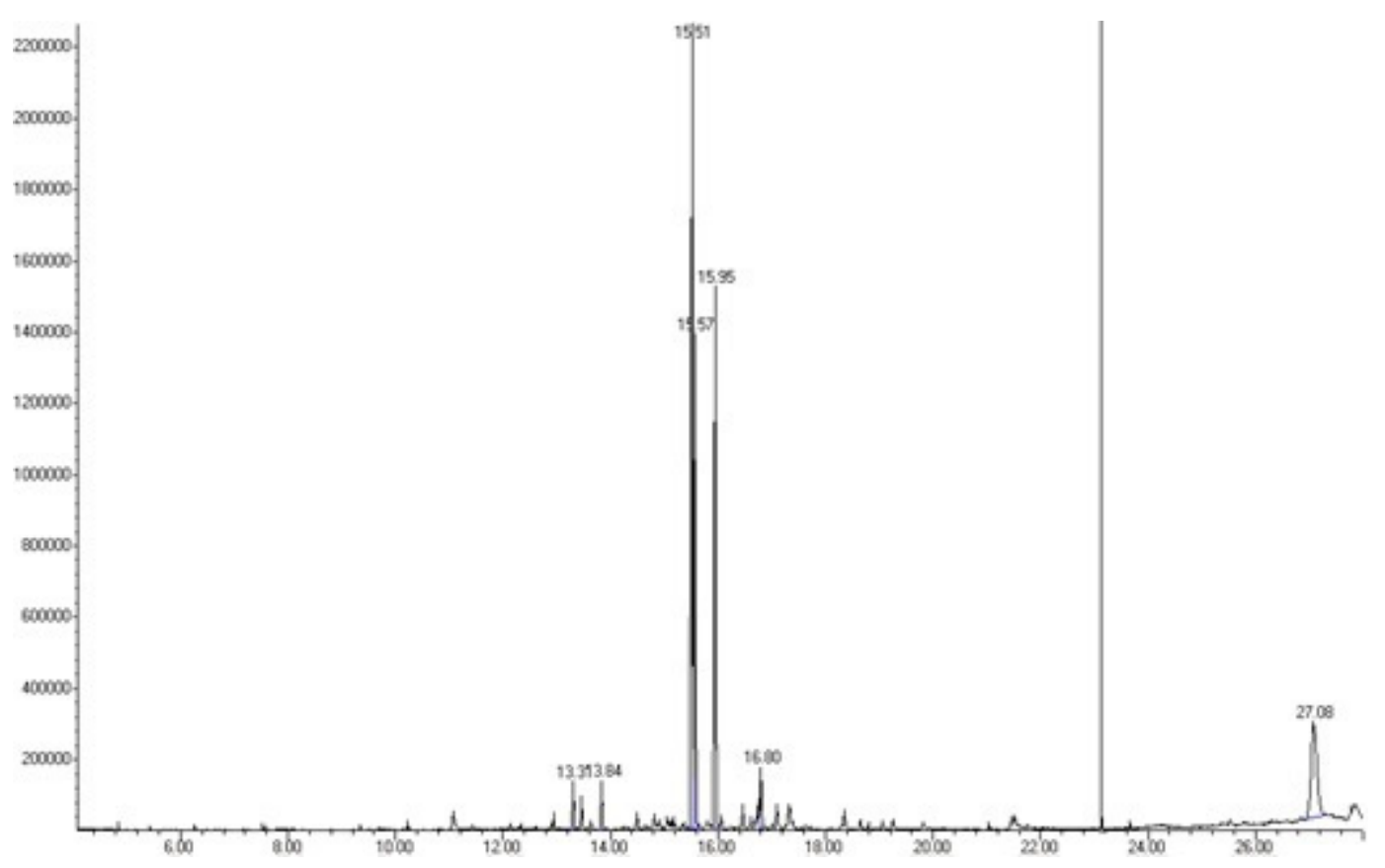

(b)

Figure 1. Chromatograms obtained from GC-MS screening of the aqueous extracts of E. cadamomum seeds (a), and C. longa roots $(\mathbf{b})$.

\subsection{Gene Expression of Anti-Inflammatory Cytokines}

The gene expression levels of the anti-inflammatory cytokines, Il-4 $(p<0.01)$ and Il-10 $(p<0.001)$, were analyzed to evaluate whether the aqueous extracts have an immunomodulatory effect on the expression of cytokines that regulate or promote inflammatory processes in peritoneal macrophages by using LPS as inflammation control (Table 5).

Table 5. Cytokines gene expression.

\begin{tabular}{cccc}
\hline Cytokine & C. longa & E. cardamomum & LPS \\
\hline IL-4 & $5.07 \pm 1.6$ & $0.30 \pm 0.185$ & 0.00 \\
IL-6 & $2.21 \pm 0.04$ & $1.05 \pm 0.012$ & $5.61 \pm 0.284$ \\
IL-10 & $1.84 \pm 0.87$ & $2.02 \pm 0.026$ & $0.90 \pm 0.073$ \\
TNF- $\alpha$ & $1.46 \pm 0.97$ & $0.086 \pm 0.070$ & $4.59 \pm 2.132$ \\
\hline
\end{tabular}

A significant increase in IL-10 gene expression level (Figure 2a) was observed with C. longa extract compared to E. cardamomum ( $p \leq 0.05$ ), as well as the same degree of significance compared to LPS ( $p \leq 0.01)$; however, when IL-4 gene expression was analyzed, highly significant differences were observed between both aqueous extracts $(p<0.01)$ and highly significant differences $(p \leq 0.001)$ were also observed between the LPS control and both extracts (Figure $2 b$ ). These results suggest that after induction with LPS, the extracts exhibited a decrease in the inflammatory process produced by bacterial endotoxins (LPS), therefore, we can consider those extracts as modulators in inflammatory processes in the presence of Gram-negative microorganisms. 
IL-10 Expression

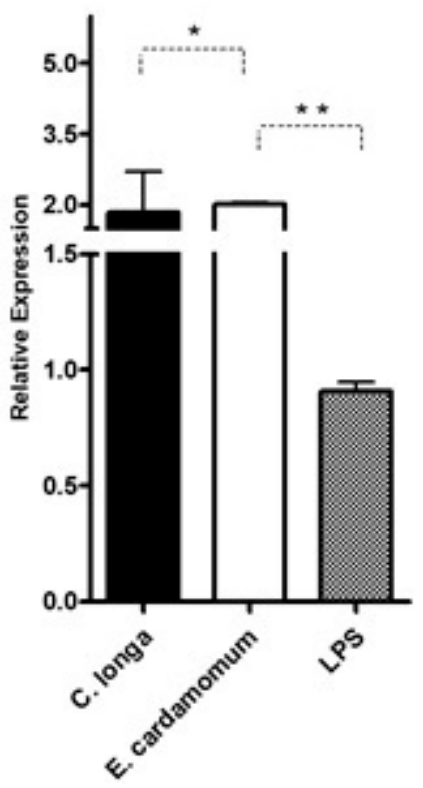

(a)

\section{IL-6 Expression}

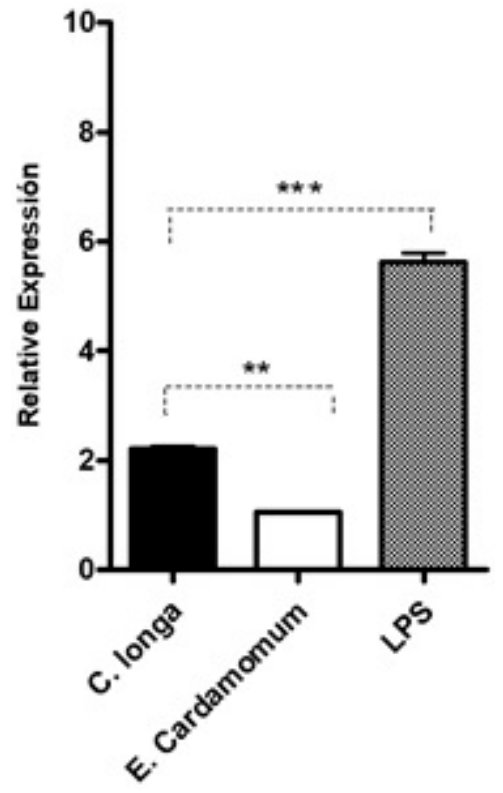

(c)
IL-4 Expression

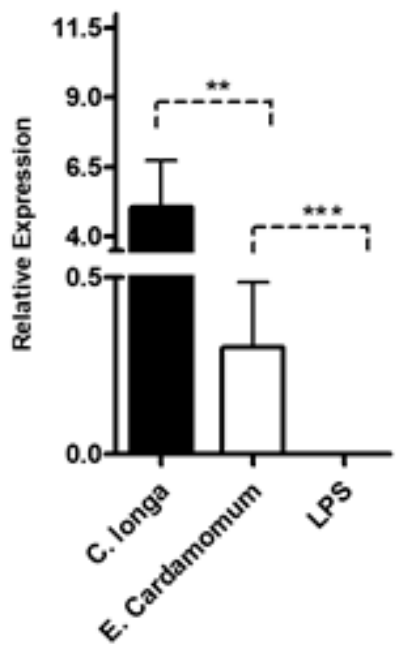

(b)

TNF- $\alpha$ Expression

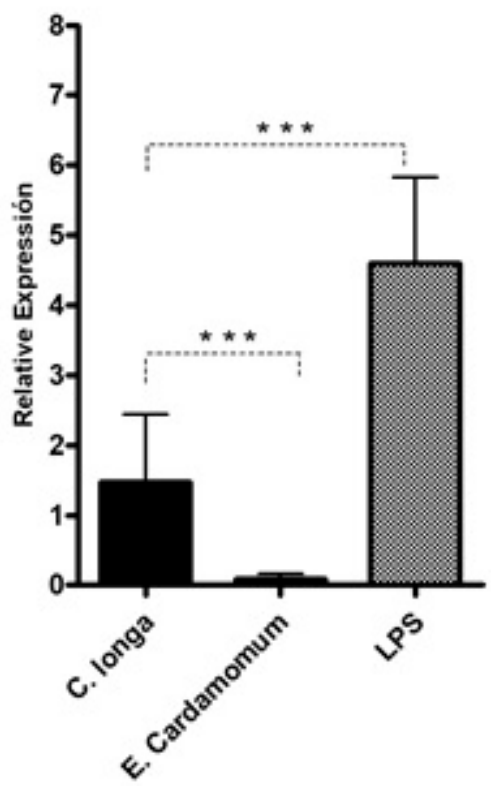

(d)

Figure 2. Gene expression of pro-inflammatory cytokines IL-10 (a), IL-4 (b) IL-6 (c), and TNF- $\alpha$ (d) in peritoneal macrophages stimulated by aqueous extracts of E. cardamomum and C. longa, challenged with LPS. ${ }^{*} p<0.05,{ }^{* *} p<0.01,{ }^{* * *} p<0.001$.

Highly significant $(p<0.001)$ decreases in the gene expression levels of proinflammatory cytokines IL-6 (Figure 2c) induced by aqueous extracts of both plants compared to LPS were observed (Table 5). Similar results were obtained for TNF- $\alpha$ (Figure 2d), which is a potent proinflammatory interleukin, observing highly significant decreases $(p \leq 0.001)$ for the treatments of each of the extracts with respect to the LPS control. The results presented in Figure 2 and Table 5 reveal that the extracts evaluated decreased the gene expression of proinflammatory cytokines, showing differences in expression in relation to 
that produced by LPS, which makes them potential natural active ingredients to reduce inflammatory processes.

\subsection{Cytotoxic Activity of the Aqueous Extract}

For the evaluation of the cytotoxicity of aqueous extracts of E. cardamomum and C. longa, three cell lines, HeLa, J774A.1, and Vero E6, and peritoneal cells of female Balb/C mice were used (Table 6). A dose-response relationship was observed, as cytotoxicity enhanced as the concentrations of the extracts increased. However, no high activity was observed against the cell lines or in peritoneal cells at the concentrations tested; E. cardamomum presented $\mathrm{EC}_{50}$ higher than $321.20 \mu \mathrm{g} / \mathrm{mL}$ on the three cell lines tested, while the $\mathrm{EC}_{50}$ of C. longa was higher than $190.79 \mu \mathrm{g} / \mathrm{mL}$. E. cardamomum was the most active on J774A.1 $\left(\mathrm{EC}_{50} 237.36 \mu \mathrm{g} / \mathrm{mL}\right.$ ) and Vero $\mathrm{E} 6\left(\mathrm{EC}_{50} 257.51 \mu \mathrm{g} / \mathrm{mL}\right)$, while $C$. longa was more effective on HeLa $\left(\mathrm{EC}_{50} 351.17 \mu \mathrm{g} / \mathrm{mL}\right)$. No differences were observed between the activities of the aqueous extracts when evaluated in peritoneal macrophages.

Table 6. Cell cytotoxicity assay.

\begin{tabular}{|c|c|c|c|c|c|c|c|c|}
\hline \multirow[b]{3}{*}{$\begin{array}{c}\text { Concentration } \\
\mu \mathrm{g} / \mathrm{mL}\end{array}$} & & & & \multicolumn{5}{|c|}{ Cell Cytotoxicity Percent (\%) } \\
\hline & \multicolumn{4}{|c|}{ Elettaria cardamomum } & \multicolumn{4}{|c|}{ Curcuma longa } \\
\hline & HeLa & J774A.1 & Vero E6 & $\begin{array}{c}\text { Balb/C } \\
\text { Peritoneal } \\
\text { Cells }\end{array}$ & HeLa & J774A.1 & Vero E6 & $\begin{array}{c}\text { Balb/C } \\
\text { Peritoneal } \\
\text { Cells }\end{array}$ \\
\hline 3.125 & $8.26^{\mathrm{a}}$ & $4.11^{\mathrm{a}}$ & $4.14^{\mathrm{a}}$ & $11.73^{\mathrm{a}}$ & $2.18^{a}$ & $11.74^{\mathrm{a}}$ & $8.34^{\mathrm{a}}$ & $2.18^{\mathrm{a}}$ \\
\hline 6.25 & $10.17^{a}$ & $10.28^{b}$ & $4.57^{\mathrm{a}}$ & $14.07^{\mathrm{a}}$ & $8.23^{b}$ & $14.06^{\mathrm{a}}$ & $10.18^{\mathrm{a}}$ & $8.23^{b}$ \\
\hline 12.5 & $13.03^{\mathrm{a}}$ & $13.73^{b}$ & $8.39^{b}$ & $14.33^{\mathrm{a}}$ & $9.59^{b}$ & $14.35^{\mathrm{a}}$ & $19.03^{b}$ & $9.59^{b}$ \\
\hline 25 & $13.51^{\mathrm{a}}$ & $22.26^{c}$ & $12.71^{b}$ & $16.23^{\mathrm{a}}$ & $13.85^{b}$ & $16.24^{\mathrm{a}}$ & $21.76^{\mathrm{b}}$ & $13.85^{\mathrm{b}}$ \\
\hline 50 & $19.47^{\mathrm{b}}$ & $31.31^{\mathrm{c}}$ & $13.04^{b}$ & $17.60^{\mathrm{a}}$ & $14.63^{\mathrm{b}}$ & $17.62^{a b}$ & $22.44^{\mathrm{b}}$ & $14.63^{\mathrm{b}}$ \\
\hline 100 & $20.58^{b}$ & $37.94^{c}$ & $19.54^{\mathrm{c}}$ & $20.37^{a b}$ & $22.16^{\mathrm{c}}$ & $20.39 \mathrm{ab}$ & $25.81^{b}$ & $22.16^{c}$ \\
\hline 200 & $21.93^{b}$ & $45.33^{\mathrm{d}}$ & $35.21^{d}$ & $27.20^{b}$ & $22.92^{\mathrm{c}}$ & $27.21^{b}$ & $26.41^{b}$ & $22.92^{c}$ \\
\hline $\mathrm{EC}_{50} \mu \mathrm{g} / \mathrm{mL}$ & 424.01 & 237.36 & 257.51 & 431.16 & 351.17 & 430.96 & 396.24 & 362.86 \\
\hline LL & 372.09 & 190.79 & 191.02 & 287.35 & 321.20 & 381.60 & 349.78 & 269.66 \\
\hline UL & 473.84 & 261.68 & 301.23 & 582.74 & 382.14 & 480.33 & 442.71 & 509.85 \\
\hline $\mathrm{EC}_{90} \mu \mathrm{g} / \mathrm{mL}$ & 890.09 & 423.17 & 436.37 & 838.33 & 721.65 & 957.64 & 931.97 & 705.80 \\
\hline LL & 811.96 & 412.91 & 402.75 & 690.10 & 705.80 & 934.98 & 905.02 & 596.56 \\
\hline UL & 988.53 & 434.32 & 478.67 & 983.15 & 757.78 & 982.90 & 962.03 & 831.34 \\
\hline
\end{tabular}

The table shows the mean $\mathrm{EC}_{50}$ and $\mathrm{EC}_{90}$. The lower (LL) and upper limits (UL) are shown. Different letters in each column represent significant differences between the groups analyzed via the Tukey post hoc test.

\subsection{Nitric Oxide Depletion in Peritoneal Macrophages}

NO production was measured as an indicator of inflammation in peritoneal macrophages. Nitric oxide production averaged 22.12, 18.64, 10.91, and $7.45 \mu \mathrm{M}$ nitrite for macrophages stimulated with LPS, LPS plus E. cardamomum extract, E. cardamomum extract alone, and without stimulation, respectively, while for $C$. longa, the results were 22.27, 16.97, 8.03, and $6.73 \mu \mathrm{M}$ nitrite under the same treatments, showing significant differences $(p<0.001)$ when macrophages were incubated with $50 \mathrm{ng} / \mathrm{mL}$ LPS to induce an activation state (Figure 3). 


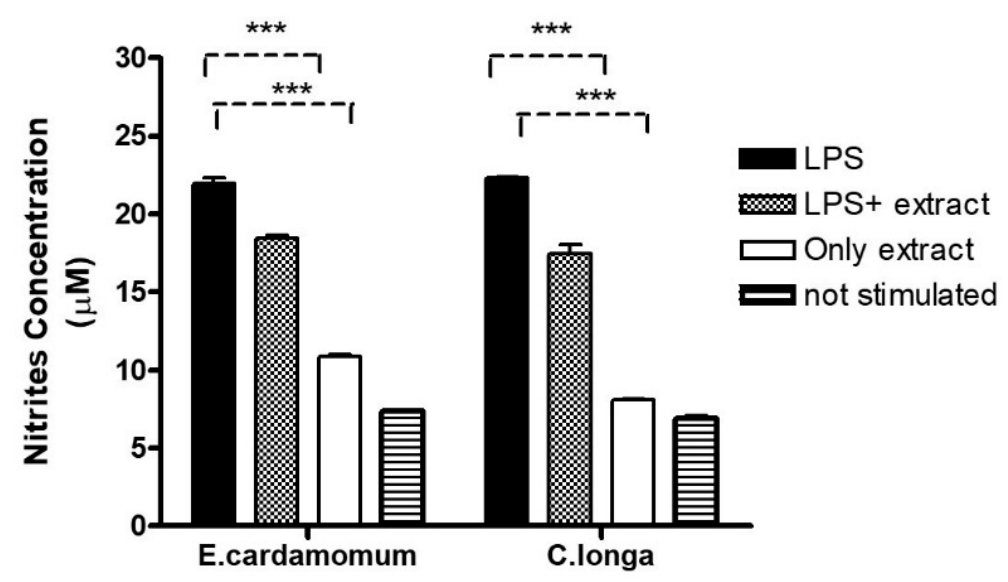

Figure 3. Nitric oxide production in peritoneal macrophages stimulated with $100 \mu \mathrm{g} / \mathrm{mL}$ of aqueous extracts of E. cardamomum, and $70 \mu \mathrm{g} / \mathrm{mL}$ of $C$. longa, challenged with $50 \mu \mathrm{g} / \mathrm{mL}$ of LPS. ${ }^{* * *} p<0.001$.

\section{Discussion}

The use and evaluation of the traditional folk plants E. cardamomum and C. longa in terms of their anti-inflammatory activities have been remarkable because of the positive results obtained in several studies where these plants have been used to reduce the symptoms of various chronic inflammatory diseases [28]. In the development of such research, numerous bioactive compounds present in its essential oils have been identified, which differ in proportions and presence depending on the region where the plant was collected, the time of collection, or the type of extraction [13]. In the chemical characterization of E. cardamomum and C. longa, a series of major compounds were identified in the crude extracts of both plants, which largely comprise the composition of their essential oils, showing their participation in the immune response by acting as mediators in the synthesis of key factors of the immune response [29].

In the present investigation, the compounds identified as major in E. cardamomum have been previously reported as components of its essential oils [30]. We determined the anti-inflammatory activity of the aqueous extract of this plant, which coincides with previous reports [13], and while this activity is justified by the compound 1,8-cineole, this was not one of the majority compounds of the crude extract obtained by us. Instead, the combined activity of the compounds 9-hexacosene, $\alpha$-terpinol, and linalool represents an alternative option for bioactive compounds with anti-inflammatory activity derived from this plant. Previous reports demonstrated the activity of 9-hexacosene in reducing the size of edema in mouse ears, induced by dimethylbenzene [31]; on the other hand, the ability of $\alpha$-terpinol to suppress pro-inflammatory mediators generating an inhibition of IL-6 has been identified [32]. Similarly, in previous works, it was reported that linalool generates a reduction of TNF- $\alpha$ in addition to an inhibition of neutrophil activation [33]. Regarding the compound $\alpha$-terpenyl acetate, the major compound in our E. cardamomum extract, it has not been previously associated with anti-inflammatory activity. Although this compound has been previously reported in plants with anti-inflammatory activity [13,34-36], including the plant under study, there is a lack of evaluations demonstrating such activity, which represents an opportunity to consider for future research because, in E. cardamomum, this is a majority compound of its essential oils.

The compounds identified as major in the aqueous extract of $C$. longa have been previously reported [37]. Meanwhile, the anti-inflammatory activity exhibited by this plant has been generally associated with curcuminoids, specifically curcumin [38]. However, curcuminoids were not identified in our aqueous extract of $C$. longa; instead, turmerones (AR, $\alpha$, and $\beta$ ) were identified as major compounds, which have not received extensive investigation in regards to their anti-inflammatory activity. In this regard, there have been some reports of the anti-inflammatory properties of turmeric essential oils [29], where Ar-turmerone and $\beta$-sesquiphellandrene have been reported as the main components 
considered responsible for such activity [39], specifically the ability of Ar-turmerone to inhibit the production of INF- $\gamma$ and IL-2 [40]. Thus, it is possible to demonstrate the ability to induce the expression of anti-inflammatory interleukins and inhibition of proinflammatory interleukins, justifying the use of extracts from C. longa or E. cardamomum as a treatment for inflammatory conditions.

Different research demonstrated the close relationship between food and health, highlighting the benefits of vitamins, minerals, fatty acids, probiotics, prebiotics, or phytochemicals in fighting various diseases [41]. Among them, the role of substances of plant origin, such as carotenoids, phenolic compounds, alkaloids, nitrogen, and organosulfur compounds, should be marked for their demonstrated influence on the immune system [42].

Some of the immune processes that take place when infections occur are mainly the excessive production of proinflammatory cytokines, including IL-6, IFN- $\gamma$, IL- $1 b$, and TNF- $\alpha$. Such expression has been closely related to apoptosis-inducing inflammatory processes in animal models [25]. Neutrophil infiltration can lead to damage stimulated by oxidative stress, which increases inflammation and activation of nuclear factor-kappa beta (NF-kB)-dependent pathways. NF-kB induces the production of cyclooxygenase 2 (COX-2), which promotes the production of prostaglandins and other inflammatory agents of the metabolic pathway involved in inflammatory diseases [43]. The presence of the enzyme inducible nitric oxide synthase (iNOS) and COX-2 induces damage associated with excessive production of reactive oxygen species (ROS) and suppression of the antioxidative and defense system [44]. The regulation of iNOS for nitric oxide production will determine whether this will be associated with damage or repair [24]. Some reports have indicated that, in the case of inflammatory processes, chronic inflammation is largely due to uncontrolled production of nitric oxide (NO) by mucosal cells-in this situation nitric oxide may not be properly regulated by iNOS [45]. The arginine pathway plays an important role in tissue repair as L-arginine is converted to an amino acid after tissue injury. Some studies have indicated that arginine increases collagen deposition and tear strength (effects that contribute to epithelial repair and arginase repair functions associated with inflammatory processes); this enzyme inhibits nitric oxide synthesis, resulting in limited intracellular L-arginine supply to produce reactive nitrogen species (RNS) [46], decreasing mucosal damage, such as oral.

In a study conducted in hamsters in which an inflammatory process was induced through local lacerations and a potent inflammatory agent such as 5-fluorouracil, it was observed that daily topical treatment with extracts of Calendula officinalis on days 12 to 17 after the inflammatory induction reduced the clinical severity of the disease in a concentrationdependent manner, compared to animals treated only with the vehicle-this is another example of how natural extracts are a good option in the management of lesions [47]. Another study demonstrated the anti-inflammatory effect of chamomile extracts by inhibiting the expression of IL-1 $\beta$ and TNF- $\alpha$ cytokines in an animal model, with data like those observed in our research; however, they could also prove it at the histopathological level, supporting the idea of the use of plant extracts as possible natural candidates in the management of inflammatory processes [48]. In another study, the anti-inflammatory effect of cardamom extracts was demonstrated by inhibiting the action of macrophages producing proinflammatory cytokines such as Il- $1 \beta$, TNF- $\alpha$, and Il- 8 through the effect of LPS from Actinobacillus actinomycetemcomitans [13]. On the other hand, using a mouse peritoneal macrophage model, the ability of an aqueous extract of cardamom to attenuate IL-6 and TNF- $\alpha$ secretion was demonstrated [49]. It has been suggested that the antiinflammatory activity of cardamom extracts reported by other authors is related to the presence of phytochemical agents in high amounts, in this case to 1,8-cineole (eucalyptol), since this compound has also been shown to attenuate LPS-induced inflammatory signaling pathways in the lung by alveolar macrophages [50].

The present investigation found a positive response of almost 6 relative units of expression for IL-6. The technique was proved valid by positive controls in alpaca enterocytes, which indicated its scarce participation as an inducer of the acute phase of inflammation 
where leukocytes participate-IL-6 has anti-inflammatory as well as pro-inflammatory effects by regulating the expression of other pro-inflammatory cytokines and, in addition, it induces the synthesis of glucocorticoids [51]. Quantification of cytokine and receptor mRNA was performed by RT-qPCR, from which the results showed positive responses, specifically of $C$. longa concerning IL-10, which is the interleukin responsible for regulating and decreasing the inflammatory response produced by dendritic cells and macrophages, and also for reducing the adaptive responses of CD4 T cells and IL-4, which is a cytokine that acts as an anti-inflammatory by blocking the synthesis of IL-1, TNF- $\alpha$, IL-6, and macrophage inflammatory protein [52]. The proinflammatory activity of INF- $\gamma$, which is produced in T cells and activated NK cells, was also observed. It potentiates the effects of type I interferons released by Th1, which regulates leukocytes at the site of infection, giving rise to inflammation [53]. As for IL-6, the results dictate a positive response since this interleukin shows anti-inflammatory as well as pro-inflammatory activity [54]. In addition, the extract also influenced the proinflammatory cytokine TNF- $\alpha$, which also leads to the recruitment of inflammatory cells.

Several in vitro studies in human cell lines have demonstrated the cytotoxic capacity of several natural extracts [55,56] such as curcuminoids [16]. Different components of Zingiberaceae plants can suppress the activity of some common mutagens and carcinogens in various cell types in both in vitro and in vivo studies. The cytotoxic effects of methanol extracts and their fractions (hexane, ethyl acetate, and water) of Alpinia mutica rhizomes against six human carcinoma cell lines (KB, MCF7, A549, Caski, HCT116, HT29) and the non-human fibroblast cell line (MRC 5) are currently known as a result of an in vitro cytotoxicity assay [57]. In two studies on colon and prostate cancer, curcumin from C. longa inhibited cell proliferation and tumor growth [58]. In addition, curcumin is a nonmutagenic and nongenotoxic agent [15]. Although the cytotoxic activity of curcuminoids is known, in this research, promising results were observed in terms of anti-inflammatory activity, but no cytotoxic activity was observed in HeLa, J774A.1, Vero E6, and peritoneal cell lines, as the $\mathrm{EC}_{50}$ values found were higher than $200 \mu \mathrm{g} / \mathrm{mL}$ and $\mathrm{EC}_{90}$ values were higher than $400 \mu \mathrm{g} / \mathrm{mL}$, respectively, for all assays evaluated (Table 6).

Currently, there is a growing interest in both industry and scientific research on spices and aromatic herbs due to their strong antioxidant powers and antimicrobial propertiesboth natural and synthetic antioxidants are currently being used. In some of these studies, microbicidal activity against Streptococcus mutans was observed with an increase of nitric oxide in RAW 264.7 macrophages stimulated with extracts of Rosmarinus officinalis, Thymus vulgaris, and C. longa [59]. Another study showed that curcumin at a dose of $0.5 \mathrm{ppm}$ induced polarization to an M2 phenotype or alternating activation with anti-inflammatory characteristics in peritoneal macrophages, although at higher doses this phenotype was lost and they observed increased expression at the level of Arg- 1 transcripts, which is a competitor of L-Arginine against iNOS enzymes [60]. When we stimulated macrophages with LPS in the presence of the extracts, nitrite production decreased, in addition to the fact that the extract alone induced little nitrite production without stimulation in both aqueous extracts. These data suggest the anti-inflammatory effect of the extracts alone or in combination with LPS (Figure 3). At the moment, the modulatory effects of turmeronole A and B (plant components of the C. longa) on RAW 264.7 cells in inflammatory processes are known - they significantly inhibited LPS-induced prostaglandin E (PgE) and NO production, as well as the expression of iNOS and the gene encoding PgE. In addition, turmeronols significantly inhibited the overexpression of transcripts encoding IL-1 $\beta$, IL-6, and TNF- $\alpha$ at the mRNA and protein level induced by LPS [61].

In addition, several investigations carried out with the main components in plants of this family have demonstrated their antioxidant capacity against the DPPH radical in comparison with Trolox and ascorbic acid-among the most important ones are $\alpha$-turmerone, $\beta$-turmerone, and Ar-turmerone [62]. In an investigation to evaluate the hepatoprotective effect of an extract of Amomum cardamomum on carbon-tetrachloride-induced liver damage through antioxidant activity in rats, it was found to possess significant hepatoprotective 
activity on acute liver injury, which could be derived from its antioxidant properties and the decrease of liver cytochrome P450 [63]. In general, it can be stated that the pharmaceutical properties of plants of the Zingiberaceae family are related to their chemical composition; this is mainly due to the presence of phenolic compounds and other biologically active constituents [11]. In addition to anticancer, antioxidant, and free radical scavenging effects, these plants possess the capacity to indirectly increase glutathione levels, thus aiding in the hepatic detoxification of mutagens and carcinogens and inhibiting the formation of nitrosamines [58].

We think that the results presented in this manuscript may be sufficient to infer the anti-inflammatory effects of the extracts in question, given that several investigations have provided evidence such as those presented in this document-in the case of E. cardamomum, some authors have mentioned the anti-inflammatory properties $[13,49]$ and for $C$. longa, some authors described these same effects through the suppression of $\mathrm{NO}$ and COX $[64,65]$.

\section{Conclusions}

Under the experimental conditions analyzed and based on the results obtained in the tests performed in this research, the anti-inflammatory effects of E. cardamomum and C. longa were evidenced. The aqueous extracts of cardamom and turmeric showed elevated expression of interleukins, suggesting their possible anti-inflammatory or immunomodulatory action. As for the cytotoxic action, a dose-response relationship was observed, since as the concentration increased, the cytotoxic activity increased. The concentrations evaluated (from 3.125 to $200 \mu \mathrm{g} / \mathrm{mL}$ ) showed no activity against HeLa, J774A.1 and Vero E6 cell lines. In future research, we expect to continue with more studies to identify the molecular mechanisms of action that favors the use of these plants as complementary alternatives in inflammatory processes in order to develop alternative or adjuvant therapies, as well as safe applications of cardamom and turmeric, which could bring several benefits, such as cost reduction compared to existing products, in addition to contributing to the ethno-pharmacological development for the safe use of folk traditional plants.

Author Contributions: Conceptualization, O.E.R.L. and R.A.P.H.; correspondence, U.C.V. and O.E.R.L.; methodology, S.M.L.V. and A.F.B.R.; software, J.R.R. and R.A.P.H.; validation, R.M.S.C., A.C.M., and A.F.B.R.; formal analysis, G.R.C.G. and A.C.M.; investigation, A.J.M.D.; resources, S.M.L.V.; data curation, J.H.E.L. and U.C.V.; writing-original draft preparation, G.R.C.G. and O.E.R.L.; writing — review and editing, O.E.R.L. and J.H.E.L.; visualization, S.M.L.V.; supervision, J.R.R.; project administration and funding acquisition, O.E.R.L. and R.A.P.H. All authors have read and agreed to the published version of the manuscript.

Funding: This research was funded by the National Council of Science and Technology (CONACYT, Mexico), grant number 958507, as well as the Support Program for Scientific and Technological Research (PAICYT-UANL 2021), and the Professional Development Program for Higher Education (PRODEP). This publication was also supported by the Institutional Open Access Program (IOAP) of the Tecnológico de Monterrey.

Institutional Review Board Statement: The laboratory animal study was conducted according to the guidelines of the Declaration of Helsinki and approved by the Institutional Ethics Committee of the Faculty of Veterinary Medicine and Zootechny, Autonomous University of Nuevo León protocol code 02/21-2021 (July of 2021).

Informed Consent Statement: Not applicable.

Data Availability Statement: The data presented in this research are available on request from the corresponding author.

Acknowledgments: We thank the personnel of the Laboratory of Analytical Chemistry (Faculty of Biological Sciences, Autonomous University of Nuevo León) and the Laboratory of Microbiology (Faculty of Dentistry, Autonomous University of Nuevo León) for their valuable technical assistance during the present investigation.

Conflicts of Interest: The authors declare no conflict of interest. 


\section{References}

1. Sánchez-Ramos, M.; Alvarez, L.; Romero-Estrada, A.; Bernabé-Antonio, A.; Marquina-Bahena, S.; Cruz-Sosa, F. Establishment of a cell suspension culture of ageratina pichinchensis (Kunth) for the improved production of anti-inflammatory compounds. Plants 2020, 9, 1398. [CrossRef] [PubMed]

2. Elizondo-Luévano, J.H.; Castro-Ríos, R.; Sánchez-García, E.; Hernández-García, M.E.; Vargas-Villarreal, J.; Rodríguez-Luis, O.E.; Chávez-Montes, A. In vitro study of antiamoebic activity of methanol extracts of argemone mexicana on trophozoites of entamoeba histolytica HM1-IMSS. Can. J. Infect. Dis. Med. Microbiol. 2018, 2018, 7453787. [CrossRef] [PubMed]

3. Frencken, J.E.; Sharma, P.; Stenhouse, L.; Green, D.; Laverty, D.; Dietrich, T. Global epidemiology of dental caries and severe periodontitis-A comprehensive review. J. Clin. Periodontol. 2017, 44, S94-S105. [CrossRef]

4. Soehnlein, O.; Steffens, S.; Hidalgo, A.; Weber, C. Neutrophils as protagonists and targets in chronic inflammation. Nat. Rev. Immunol. 2017, 17, 248-261. [CrossRef]

5. Konkel, J.E.; O’Boyle, C.; Krishnan, S. Distal consequences of oral inflammation. Front. Immunol. 2019, 10, 1403. [CrossRef]

6. Scannapieco, F.A.; Cantos, A. Oral inflammation and infection, and chronic medical diseases: Implications for the elderly. Periodontology 2016, 72, 153-175. [CrossRef] [PubMed]

7. Rider, P.; Carmi, Y.; Cohen, I. Biologics for targeting inflammatory cytokines, clinical uses, and limitations. Int. J. Cell Biol. 2016, 2016, 9259646. [CrossRef] [PubMed]

8. Cardoso, E.M.; Reis, C.; Manzanares-Céspedes, M.C. Chronic periodontitis, inflammatory cytokines, and interrelationship with other chronic diseases. Postgrad. Med. 2018, 130, 98-104. [CrossRef]

9. Dini, M. Peptic ulcer disease and non-steroidal anti-inflammatory drugs. Aust. Prescr. 2017, 40, 91-93.

10. Little, P. Non-steroidal anti-inflammatory drugs and covid-19. BMJ 2020, 368, m1185. [CrossRef] [PubMed]

11. Ivanović, M.; Makoter, K.; Razboršek, M.I. Comparative study of chemical composition and antioxidant activity of essential oils and crude extracts of four characteristic zingiberaceae herbs. Plants 2021, 10, 501. [CrossRef]

12. Rajan, A.; Rajan, A.R.; Philip, D. Elettaria cardamomum seed mediated rapid synthesis of gold nanoparticles and its biological activities. Open Nano 2017, 2, 1-8. [CrossRef]

13. Souissi, M.; Azelmat, J.; Chaieb, K.; Grenier, D. Antibacterial and anti-inflammatory activities of cardamom (Elettaria cardamomum) extracts: Potential therapeutic benefits for periodontal infections. Anaerobe 2020, 61, 102089. [CrossRef]

14. Tanvir, E.M.; Hossen, M.S.; Hossain, M.F.; Afroz, R.; Gan, S.H.; Khalil, M.I.; Karim, N. Antioxidant properties of popular turmeric (Curcuma longa) varieties from Bangladesh. J. Food Qual. 2017, 2017, 8471785. [CrossRef]

15. Soleimani, V.; Sahebkar, A.; Hosseinzadeh, H. Turmeric (Curcuma longa) and its major constituent (curcumin) as nontoxic and safe substances: Review. Phyther. Res. 2018, 32, 985-995. [CrossRef] [PubMed]

16. Elizondo-Luévano, J.H.; Hernández-García, M.E.; Pérez-Narváez, O.A.; Castro-Ríos, R.; Chávez-Montes, A. Berberina, curcumina y quercetina como potenciales agentes con capacidad antiparasitaria. Rev. Biol. Trop. 2020, 68, 1241-1249. [CrossRef]

17. White, C.M.; Pasupuleti, V.; Roman, Y.M.; Li, Y.; Hernandez, A.V. Oral turmeric/curcumin effects on inflammatory markers in chronic inflammatory diseases: A systematic review and meta-analysis of randomized controlled trials. Pharmacol. Res. 2019, 146, 104280. [CrossRef]

18. Elizondo-Luevano, J.H.; Verde-Star, J.; González-Horta, A.; Castro-Ríos, R.; Hernández-García, M.E.; Chávez-Montes, A. In Vitro Effect of Methanolic Extract of Argemone mexicana against Trichomonas vaginalis. Korean J. Parasitol. 2020, 58, 135-145. [CrossRef]

19. Parekh, J.; Chanda, S.V. In vitro antimicrobial activity and phytochemical analysis of some Indian medicinal plants. Turkish J. Biol. 2007, 31, 53-58.

20. Bekinbo, M.; Tariah FS, A.; Dapper, D. Comparative GC-MS determination of bioactive constituents of the methanolic extracts of Curcuma longa rhizome and Spondias mombin leaves Bekinbo MT, Amah-Tariah FS and Dapper DV. J. Med. Plants Stud. 2020, 8, $1-6$.

21. Masoumi-Ardakani, Y.; Mandegary, A.; Esmaeilpour, K.; Najafipour, H.; Sharififar, F.; Pakravanan, M.; Ghazvini, H. Chemical composition, anticonvulsant activity, and toxicity of essential oil and methanolic extract of Elettaria cardamomum. Planta Med. 2016, 82, 1482-1486. [CrossRef]

22. Salvesen, Ø.; Reiten, M.R.; Espenes, A.; Bakkebø, M.K.; Tranulis, M.A.; Ersdal, C. LPS-induced systemic inflammation reveals an immunomodulatory role for the prion protein at the blood-brain interface. J. Neuroinflam. 2017, 14, 106. [CrossRef]

23. Humberto, C.H.-M.; Ricardo, G.-F.; Patricia, T.-G.; Ramiro, Q.-L.; Mario, A.S.E.; Enriqueta, M.-C.; Reyes, T.-G.; Cristina, R.-P. Antitumor activity of Pachycereus marginatus (DC.) Britton Rose extracts against murine lymphoma L5178Y-R and skin melanoma B16F10 cells. J. Med. Plants Res. 2016, 10, 635-639. [CrossRef]

24. Castillo-Velázquez, U.; Aranday-Cortés, E.; Gutiérrez-Pabello, J.A. Alternative activation modifies macrophage resistance to Mycobacterium bovis. Vet. Microbiol. 2011, 151, 51-59. [CrossRef] [PubMed]

25. Nevárez-Garza, A.M.; Castillo-Velázquez, U.; Soto-Domínguez, A.; Montes-de-Oca-Luna, R.; Zamora-Ávila, D.E.; Wong-González, A.; Rodríguez-Tovar, L.E. Quantitative analysis of TNF- $\alpha$ IL-4, and IL-10 expression, nitric oxide response, and apoptosis in Encephalitozoon cuniculi-infected rabbits. Dev. Comp. Immunol. 2018, 81, 235-243. [CrossRef] [PubMed]

26. Delgado, A.J.M.; Velázquez, U.C.; González, J.G.B.; Montes, A.C.; Villarreal, S.M.L.; García, L.E.V.; Casas, R.M.S.; Luis, O.E.R. Evaluation of the Essential Oil of Citrus paradisi as an Alternative Treatment against Candida albicans. Open J. Stomatol. 2020, 10, 258-270. [CrossRef] 
27. Adler, B.; Adler, H.; Jungi, T.W.; Peterhans, E. Interferon- $\alpha$ primes macrophages for lipopolysaccharide-induced apoptosis. Biochem. Biophys. Res. Commun. 1995, 215, 921-927. [CrossRef]

28. Chandran, B.; Goel, A. A randomized, pilot study to assess the efficacy and safety of curcumin in patients with active rheumatoid arthritis. Phyther. Res. 2012, 26, 1719-1725. [CrossRef]

29. Sandner, G.; Heckmann, M.; Weghuber, J. Immunomodulatory activities of selected essential oils. Biomolecules 2020, 10, 1139. [CrossRef]

30. Noumi, E.; Snoussi, M.; Alreshidi, M.M.; Rekha, P.D.; Saptami, K.; Caputo, L.; De Martino, L.; Souza, L.F.; Msaada, K.; Mancini, E.; et al. Chemical and biological evaluation of essential oils from cardamom species. Molecules 2018, 23, 2818. [CrossRef]

31. Githinji, C.G.; Mbugua, P.M.; Kanui, T.I.; Kariuki, D.K. Analgesic and anti-inflammatory activities of 9-Hexacosene and Stigmasterol isolated from Mondia whytei. Phytopharmacology 2012, 2, 212-223.

32. Nogueira, M.N.M.; Aquino, S.G.; Rossa, C.; Spolidorio, D.M.P. Terpinen-4-ol and alpha-terpineol (tea tree oil components) inhibit the production of IL-1 $\beta$, IL-6 and IL-10 on human macrophages. Inflamm. Res. 2014, 63, 769-778. [CrossRef] [PubMed]

33. Abe, S.; Maruyama, N.; Hayama, K.; Ishibashi, H.; Inoue, S.; Oshima, H.; Yamaguchi, H. Suppression of tumor necrosis factor-alpha-induced neutrophil adherence responses by essential oils. Mediat. Inflamm. 2003, 12, 323-328. [CrossRef]

34. Hamdan, D.I.; Abdulla, R.H.; Mohamed, M.E.; El-Shazly, A.M. Chemical composition and biological activity of essential oils of cleopatra mandarin (citrus reshni) cultivated in Egypt. J. Pharmacogn. Phyther. 2013, 5, 83-90. [CrossRef]

35. Djouahri, A.; Boualem, S.; Boudarene, L.; Baaliouamer, A. Geographic's variation impact on chemical composition, antioxidant and anti-inflammatory activities of essential oils from wood and leaves of Tetraclinis articulata (Vahl) Masters. Ind. Crops Prod. 2015, 63, 138-146. [CrossRef]

36. Valente, J.; Resende, R.; Zuzarte, M.; Gonçalves, M.J.; Lopes, M.C.; Cavaleiro, C.; Pereira, C.; Salgueiro, L.; Cruz, M.T. Bioactivity and safety profile of Daucus carota subsp. maximus essential oil. Ind. Crops Prod. 2015, 77, 218-224. [CrossRef]

37. Angel, G.R.; Menon, N.; Vimala, B.; Nambisan, B. Essential oil composition of eight starchy Curcuma species. Ind. Crop. Prod. 2014, 60, 233-238. [CrossRef]

38. Niranjan, A.; Prakash, D. Chemical constituents and biological activities of turmeric (Curcuma longa L.) -A review. J. Food Sci. Technol. 2008, 45, 109-116.

39. Liju, V.; Jeena, K.; Kuttan, R. An evaluation of antioxidant, anti-inflammatory, and antinociceptive activities of essential oil from Curcuma longa L. Indian J. Pharmacol. 2011, 43, 526-531. [CrossRef] [PubMed]

40. Oh, S.; Han, A.R.; Park, H.R.; Jang, E.J.; Kim, H.K.; Jeong, M.G.; Song, H.; Park, G.H.; Seo, E.K.; Hwang, E.S. Suppression of inflammatory cytokine production by ar-turmerone isolated from Curcuma phaeocaulis. Chem. Biodivers. 2014, 11, $1034-1041$. [CrossRef]

41. Guillamón, E. Effect of phytochemical compounds of the genus Allium on the immune system and the inflammatory response. Ars Pharm. 2018, 59, 185-196. [CrossRef]

42. Freire-González, R.A.; Vistel-Vigo, M. Caracterizacion fitoquimica de la curcuma. Rev. Cuba. Quim. 2015, 27, 9-18.

43. Dávila-Martínez, C.; Castillo-Velázquez, U.; Soto-Domínguez, A.; Nevárez-Garza, A.M.; Arce-Mendoza, A.Y.; HernandezVidal, G.; Zamora-Avila, D.E.; Rodriguez-Tovar, L.E. Immunohistochemical localization of TNF- $\alpha$ and IL-4 in granulomas of immunocompetent and immunosuppressed New Zealand white rabbits infected with Encephalitozoon cuniculi. Cytokine 2020, 130, 155055. [CrossRef] [PubMed]

44. Koppula, S.; Kumar, H.; Kim, I.S.; Choi, D.K. Reactive oxygen species and inhibitors of inflammatory enzymes, NADPH oxidase, and iNOS in experimental models of parkinsons disease. Mediat. Inflamm. 2012, 823902. [CrossRef]

45. Baranipour, S.; Kadijani, A.A.; Qujeq, D.; Shahrokh, S.; Haghazali, M.; Mirzaei, A.; Asadzadeh-Aghdaei, H. Inducible nitric oxide synthase as a potential blood-based biomarker in inflammatory bowel diseases. Gastroenterol. Hepatol. Bed Bench 2018, 11, S124-S128. [CrossRef] [PubMed]

46. Witte, M.B.; Barbul, A. Arginine physiology and its implication for wound healing. Wound Repair Regen. 2003, 11, 419-423. [CrossRef]

47. Yoshino, F.; Yoshida, A.; Nakajima, A.; Wada-Takahashi, S.; Takahashi, S.; Lee, M.C. Il Alteration of the redox state with reactive oxygen species for 5-fluorouracil-induced oral mucositis in hamsters. PLoS ONE 2013, 8, 10-15. [CrossRef]

48. Curra, M.; Martins, M.A.T.; Lauxen, I.S.; Pellicioli, A.C.A.; Sant'Ana Filho, M.; Pavesi, V.C.S.; Carrard, V.C.; Martins, M.D. Effect of topical chamomile on immunohistochemical levels of IL-1 $\beta$ and TNF- $\alpha$ in 5-fluorouracil-induced oral mucositis in hamsters. Cancer Chemother. Pharmacol. 2013, 71, 293-299. [CrossRef]

49. Majdalawieh, A.F.; Carr, R.I. In vitro investigation of the potential immunomodulatory and anti-cancer activities of black pepper (Piper nigrum) and cardamom (Elettaria cardamomum). J. Med. Food 2010, 13, 371-381. [CrossRef]

50. Yadav, N.; Chandra, H. Suppression of inflammatory and infection responses in lung macrophages by eucalyptus oil and its constituent 1,8-cineole: Role of pattern recognition receptors TREM-1 and NLRP3, the MAP kinase regulator MKP-1, and NFKB. PLoS ONE 2017, 12, e0188232. [CrossRef]

51. Adcock, I.M.; Mumby, S. Glucocorticoids. Handb. Exp. Pharmacol. 2017, 237, 171-196. [CrossRef]

52. Conlon, K.C.; Miljkovic, M.D.; Waldmann, T.A. Cytokines in the treatment of cancer. J. Interferon Cytokine Res. J. Int. Soc. Interferon Cytokine Res. 2019, 39, 6-21. [CrossRef]

53. Billiau, A. Anti-inflammatory properties of Type I interferons. Antivir. Res. 2006, 71, 108-116. [CrossRef] [PubMed] 
54. Holdsworth, S.R.; Can, P.Y. Cytokines: Names and numbers you should care about. Clin. J. Am. Soc. Nephrol. 2015, 10, $2243-2254$. [CrossRef]

55. Elizondo-Luévano, J.H.; Castro-Ríos, R.; Vicente, B.; Fernández-Soto, P.; López-Aban, J.; Muro, A.; Chávez-Montes, A. In vitro antischistosomal activity of the argemone mexicana methanolic extract and its main component berberine. Iran. J. Parasitol. 2021, 16, 91-100. [CrossRef] [PubMed]

56. Elizondo-Luévano, J.H.; Castro-Ríos, R.; López-Abán, J.; Gorgojo-Galindo, O.; Fernández-Soto, P.; Vicente, B.; Muro, A.; ChávezMontes, A. Berberine: A nematocidal alkaloid from Argemone mexicana against Strongyloides venezuelensis. Exp. Parasitol. 2021, 220, 108043. [CrossRef] [PubMed]

57. Malek, S.N.A.; Phang, C.W.; Ibrahim, H.; Wahab, N.A.; Sim, K.S. Phytochemical and cytotoxic investigations of Alpinia mutica rhizomes. Molecules 2011, 16, 583-589. [CrossRef]

58. Akram, M.; Ahmed, A.; Usmanghani, K.; Hannan, A.; Mohiuddin, E.; Asif, M. Curcuma longa and curcumin: A review article. Rom. J. Biol. 2010, 55, 65-70.

59. Berbudi, A.; Rahmi, N.; Atik, N.; Wikayani, T.; Qomarilla, N.; Rahayu, N.S.; Putri, A.C. The administration of low-dose curcuma longa extract induces $\mathrm{m} 2$ polarization in peritoneal macrophage culture. Res. J. Pharm. Technol. 2021, 14, 1079-1084. [CrossRef]

60. Figueira, L.W.; de Oliveira, J.R.; Camargo, S.E.A.; de Oliveira, L.D. Curcuma longa L. (turmeric), Rosmarinus officinalis L. (rosemary), and Thymus vulgaris L. (thyme) extracts aid murine macrophages (RAW 264.7) to fight Streptococcus mutans during in vitro infection. Arch. Microbiol. 2020, 202, 2269-2277. [CrossRef]

61. Okuda-Hanafusa, C.; Uchio, R.; Fuwa, A.; Kawasaki, K.; Muroyama, K.; Yamamoto, Y.; Murosaki, S. Turmeronol A and turmeronol B from Curcuma longa prevent inflammatory mediator production by lipopolysaccharide-stimulated RAW264.7 macrophages, partially via reduced NF-кB signaling. Food Funct. 2019, 10, 5779-5788. [CrossRef] [PubMed]

62. Ibáñez, M.D.; Blázquez, M.A. Curcuma longa 1. Rhizome essential oil from extraction to its agri-food applications. A review. Plants 2021, 10, 44. [CrossRef] [PubMed]

63. Lim, D.W.; Kim, H.; Park, J.Y.; Kim, J.E.; Moon, J.Y.; Park, S.D.; Park, W.H. Amomum cardamomum L. ethyl acetate fraction protects against carbon tetrachloride-induced liver injury via an antioxidant mechanism in rats. BMC Complement. Altern. Med. 2016, 16, 155. [CrossRef] [PubMed]

64. Lee, S.Y.; Cho, S.S.; Li, Y.C.; Bae, C.S.; Park, K.M.; Park, D.H. Anti-inflammatory Effect of Curcuma longa and Allium hookeri Co-treatment via NF-kB and COX-2 Pathways. Sci. Rep. 2020, 10, 5718. [CrossRef]

65. Lee, T.K.; Trinh, T.A.; Lee, S.R.; Kim, S.; So, H.M.; Moon, E.; Hwang, G.S.; Kang, K.S.; Kim, J.H.; Yamabe, N.; et al. Bioactivity-based analysis and chemical characterization of anti-inflammatory compounds from Curcuma zedoaria rhizomes using LPS-stimulated RAW264.7 cells. Bioorg. Chem. 2019, 82, 26-32. [CrossRef] [PubMed] 